\title{
Prevalence of Diastolic Dysfunction in Asymptomatic Young and Middle Aged Individuals Attending a Tertiary Care Hospital
}

\author{
Rajiv Arora', Aafreen Arora ${ }^{2}$ \\ ${ }^{1}$ Associate Professor \& Chief Cardiologist, Department of Cardiology \& ICCU, Govt. Medical College/ Guru Nanak Dev Hospital \& Allied Hospital Amritsar (Punjab) \\ 143001, India, ${ }^{2} \mathrm{BDS}$ Intern, SGRD Institute of Dental Science and Research, Amritsar, Punjab, India.
}

\section{Abstract}

Background: Heart problem is a common health issue encountered these days. Hence; the present study was planned for assessing the prevalence of Diastolic Dysfunction in Asymptomatic Young and Middle Aged Individuals Attending a Tertiary Care Hospital. Subjects and Methods: A total of 200 patients were included in the present study. The study group comprised of patients who reported to the department for routine medical checkup. Echocardiography using color Doppler was done in all the patients. Physical examination was done to look for any evidence of cardiac involvement in each and every patient. The diastolic dysfunction was graded as; Grade 1: An isolated early relaxation abnormality, Grade 2: Impaired relaxation, but with modestly elevated Left ventricular end-diastolic pressure, and Grade 3: Restrictive filling.All the results were recorded in Microsoft excel sheet. Results: Diastolic dysfunction was found to be present in 50 patients. Therefore; prevalence of diastolic dysfunction was found to be 25 percent. Significant increase in the prevalence of diastolic dysfunction was seen among elderly patients. However; no significant correlation was seen among patients with diastolic dysfunction divided on the basis of gender. Conclusion: Diastolic dysfunction is a major health issue affecting a significant patient population. Also, increase in severity of diastolic dysfunction is found to be positive correlated with increasing age.

Keywords: Diastolic dysfunction, Prevalence.

Corresponding Author: Dr. Rajiv Arora, Associate Professor \& Chief Cardiologist, Department of Cardiology \& ICCU, Govt. Medical College/ Guru Nanak Dev Hospital \& Allied Hospital Amritsar (Punjab) 143001, India.

Received: July 2019

Accepted: August 2019

\section{Introduction}

Since the first report of the syndrome of heart failure (HF) with a preserved ejection fraction (HFpEF) nearly 30 years ago, the diagnosis, pathophysiology, and most effective therapies for diastolic dysfunction and HFpEF caused by diastolic dysfunction (ie, diastolic HF) have remained controversial. ${ }^{[1-3]}$ One issue making the interpretation of the aforementioned reports difficult is that the prevalence of Left ventricular diastolic dysfunction (LVDD) cannot be easily compared, partially because of differing diagnostic criteria and/or divergent distributions of cardiovascular risk factors in the sampled population. ${ }^{[4-6]}$ Hence; under the light of above mentioned data, the present study was planned for assessing the prevalence of Diastolic Dysfunction in Asymptomatic Young and Middle Aged Individuals Attending a Tertiary Care Hospital.

\section{Subjects and Methods}

The present study was conducted in the Department of Cardiology, Govt Medical College, Amritsar, Punjab to assess prevalence of Diastolic Dysfunction in asymptomatic young and middle aged individuals attending a tertiary care hospital. Before the starting of the study, ethical approval was obtained. Also written consent was obtained from all the patients after explaining in detail the entire research protocol. A total of 200 patients were included in the present study. The study group comprised of patients who reported to the department for routine medical checkup. Echocardiography using color Doppler was done in all the patients. Physical examination was done to look for any evidence of cardiac involvement in each and every patient. Hematological tests like hemoglobin, white blood cell count, differential count, platelet count and prothrombin time were carried out in all the patients.

The diastolic dysfunction was graded based on echocardiographic findings based on criteria described previously in the literature as follows. ${ }^{\text {[7] }}$

Grade 1: An isolated early relaxation abnormality.

Grade 2: Impaired relaxation, but with modestly elevated Left ventricular end-diastolic pressure

Grade 3: Restrictive filling

All the results were recorded and were analyzed by SPSS software. Chi- square test was used for assessment of level of significance. 


\section{Results}

In the present study, a total of 200 patients were analyzed. Diastolic dysfunction was found to be present in 50 patients. Therefore; prevalence of diastolic dysfunction was found to be 25 percent. In the present study, among the patients with diastolic dysfunction, 50 percent had grade 1 diastolic dysfunction, 36 percent had grade 2 diastolic dysfunction, and remaining 18 percent had grade 3 diastolic dysfunction. Significant increase in the prevalence of diastolic dysfunction was seen among elderly patients. However; no significant correlation was seen among patients with diastolic dysfunction divided on the basis of gender.

Table 1: Prevalence of diastolic dysfunction

\begin{tabular}{|l|l|l|}
\hline Parameter & Number of patients & Prevalence percentage \\
\hline $\begin{array}{l}\text { Patients with } \\
\text { diastolic } \\
\text { dysfunction }\end{array}$ & 50 & 25 \\
\hline
\end{tabular}

Table 2: Distribution of patients with diastolic dysfunction on the basis of severity

\begin{tabular}{|l|l|l|}
\hline Diastolic dysfunction & Number of patients & Prevalence percentage \\
\hline $\begin{array}{l}\text { Grade } 1 \text { diastolic } \\
\text { dysfunction }\end{array}$ & 25 & 50 \\
\hline $\begin{array}{l}\text { Grade 2 diastolic } \\
\text { dysfunction }\end{array}$ & 18 & 36 \\
\hline $\begin{array}{l}\text { Grade 3 diastolic } \\
\text { dysfunction }\end{array}$ & 07 & 14 \\
\hline Total & 50 & 100 \\
\hline
\end{tabular}

Table 3: Age wise distribution of patients with diastolic dysfunction

\begin{tabular}{|l|l|l|l|l|}
\hline \multirow{2}{*}{$\begin{array}{l}\text { Diastolic } \\
\text { dysfunction }\end{array}$} & \multicolumn{3}{|c|}{ Age group } & \multirow{2}{*}{ p- value } \\
\cline { 2 - 4 } & $\begin{array}{l}\text { Less } \\
\text { than 30 } \\
\text { years }\end{array}$ & $\begin{array}{l}\text { 30 to 50 } \\
\text { years }\end{array}$ & $\begin{array}{l}\text { More } \\
\text { than 50 } \\
\text { years }\end{array}$ & \\
\hline $\begin{array}{l}\text { Grade 1 } \\
\text { diastolic } \\
\text { dysfunction }\end{array}$ & 5 & 8 & 12 & $\begin{array}{c}0.02 \\
\text { (Significant) }\end{array}$ \\
\hline $\begin{array}{l}\text { Grade 2 } \\
\text { diastolic } \\
\text { dysfunction }\end{array}$ & 4 & 6 & 8 & \\
\hline $\begin{array}{l}\text { Grade 3 } \\
\text { diastolic } \\
\text { dysfunction }\end{array}$ & 2 & 2 & 3 & \\
\hline
\end{tabular}

Table 4: Gender wise distribution of patients with diastolic dysfunction

\begin{tabular}{|l|l|l|l|}
\hline $\begin{array}{l}\text { Diastolic } \\
\text { dysfunction }\end{array}$ & Gender & p- value \\
\cline { 2 - 3 } & Males & Females & \\
\hline $\begin{array}{l}\text { Grade 1 diastolic } \\
\text { dysfunction }\end{array}$ & 13 & 12 & $\begin{array}{l}0.55 \text { (Non- } \\
\text { Significant) }\end{array}$ \\
\hline $\begin{array}{l}\text { Grade 2 diastolic } \\
\text { dysfunction }\end{array}$ & 10 & 8 & \\
\hline $\begin{array}{l}\text { Grade 3 diastolic } \\
\text { dysfunction }\end{array}$ & 4 & 3 & \\
\hline
\end{tabular}

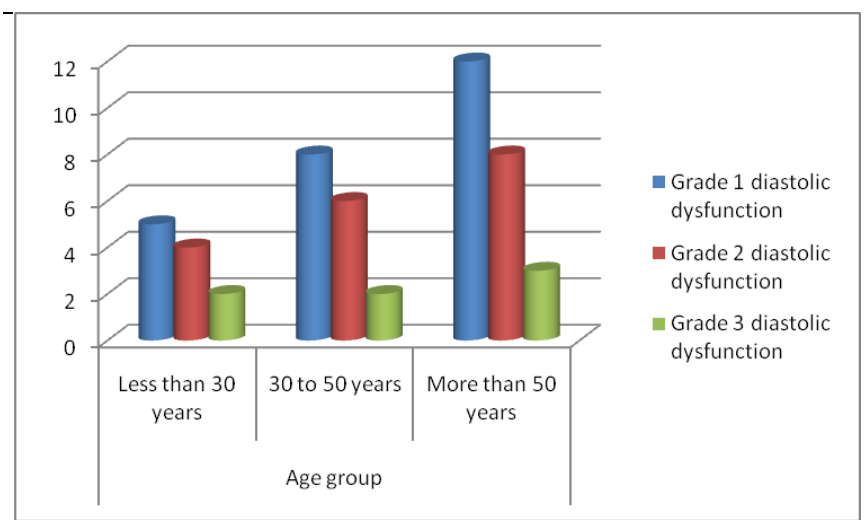

Figure 1: Age wise distribution of patients with diastolic dysfunction

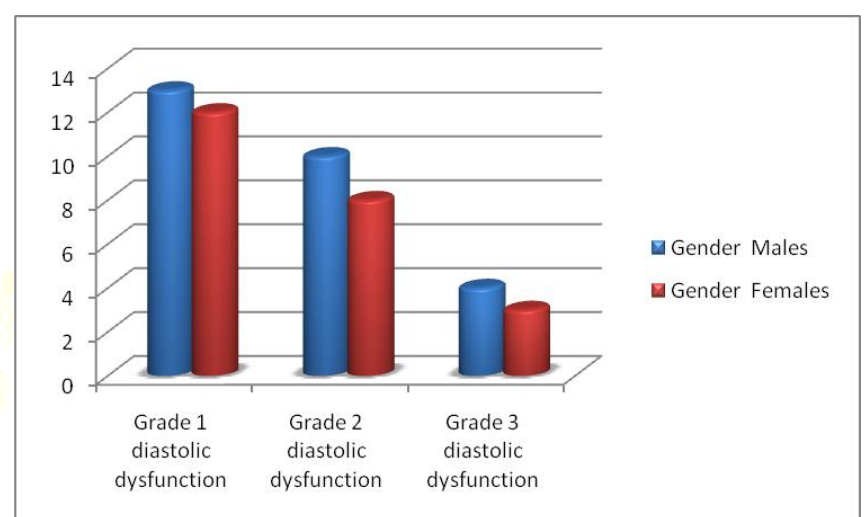

Figure 2: Gender wise distribution of patients with diastolic dysfunction

\section{Discussion}

Diastolic function reflects the ability of the heart to change its shape in order to receive blood from the venous system. This property of the heart is essential as it allows myocyte stretch and thus regulation of systolic output through activation of Frank Starling (heterometric) mechanism without necessitating a change in contractility. ${ }^{[7]}$

Some of the confusion exists because diastolic dysfunction can be present in asymptomatic patients, patients with preserved EF, and patients with reduced EF. Moreover, not all cases of HFpEF or HF with reduced EF (HFrEF) are associated with diastolic dysfunction. Therefore, the relationship of diastolic dysfunction to the clinical syndrome of HF is somewhat ill-defined ${ }^{8}$ Hence; under the light of above mentioned data, the present study was planned for assessing the prevalence of Diastolic Dysfunction in Asymptomatic Young and Middle Aged Individuals Attending a Tertiary Care Hospital.

In the present study, a total of 200 patients were analyzed. Diastolic dysfunction was found to be present in 50 patients. Therefore; prevalence of diastolic dysfunction was found to be 25 percent. Many mechanisms have been proposed. Recently, cardiac oxidative stress has been associated with diastolic dysfunction. Increased levels of cardiac reactive oxygen species (ROS) may explain some of the changes in $\mathrm{Ca} 2+$ handling proteins and the increased 
$\mathrm{Ca} 2+$ sensitivity of myofilaments in diastolic dysfunction. ${ }^{[9-11]}$ In developed countries heart failure represents a heavy epidemiological burden, with a prevalence of $1-2 \%$ of the adult population, rising to $\geq 10 \%$ among people with $>70$ years of age. Diastolic heart failure (Heart Failure with preserved Ejection Fraction, HFpEF) accounts for a relevant proportion of all HF admissions, ranging from 22 to $70 \%$ according to its definition, setting, population age and sex, with the highest prevalence in the elderly. ${ }^{[12]}$

Diastolic dysfunction may be present for several years before any symptoms occur and may represent the first phase of diastolic heart failure. Thus, it is important to detect diastolic dysfunction early and to start treatment before irreversible structural alterations and systolic dysfunction have occurred. ${ }^{[13]}$

In the present study, among the patients with diastolic dysfunction, 50 percent had grade 1 diastolic dysfunction, 36 percent had grade 2 diastolic dysfunction, and remaining 18 percent had grade 3 diastolic dysfunction. Significant increase in the prevalence of diastolic dysfunction was seen among elderly patients. However; no significant correlation was seen among patients with diastolic dysfunction divided on the basis of gender. In a previous study conducted by Fischer $\mathrm{M}$ et al, authors identified abnormal diastolic function by echocardiography in an age-stratified population-based European sample. The overall prevalence of diastolic abnormalities, as defined by the European Study Group on Diastolic Heart Failure (i.e. age dependent isovolumic relaxation time (92-105 ms) and early (E-wave) and late (A-wave) left ventricular filling (E/A-ratio, 1-0.5)) was $11.1 \%$. The prevalences of diastolic abnormalities and diastolic dysfunction are higher than that of systolic dysfunction and are increased (despite age-dependent diagnostic criteria) in the elderly. ${ }^{[12]}$ Kloch-Badelek M et al compared across populations age-specific echocardiographic criteria for diastolic LV dysfunction as well as their correlates and prevalence. The age-specific criteria for diastolic LV dysfunction were highly consistent across the study populations with an age-standardized prevalence of $22.4 \%$ vs. $25.1 \%$. ${ }^{[13]}$

\section{Conclusion}

Under the light of above obtained data, the authors conclude that diastolic dysfunction is a major health issue affecting a significant patient population. Also, increase in severity of diastolic dysfunction is found to be positive correlated with increasing age.

\section{References}

1. Maharaj R. Diastolic dysfunction and heart failure with a preserved ejection fraction: Relevance in critical illness and anaesthesia. J Saudi Heart Assoc. 2012;24:99-121.

2. Jeong EM, Dudley SC., Jr New diagnostic and therapeutic possibilities for diastolic heart failure. RI Med J. 2014;97:35-37.

3. Dougherty AH, Naccarelli GV, Gray EL, Hicks CH, Goldstein RA. Congestive heart failure with normal systolic function. Am J Cardiol. 1984;54:778-782.

4. Redfi MM, Jacobsen SJ, Burnett JC, Jr, Mahoney DW, Bailey KR, Rodeheffer RJ. Burden of systolic and diastolic ventricular dysfunction in the community: Appreciating the scope of the heart failure epidemic. JAMA. 2003;289:194-202.

5. Kass DA, Bronzwaer JG, Paulus WJ. What mechanisms underlie diastolic dysfunction in heart failure? Circ Res. 2004;94:1533-1542.

6. Halley CM, Houghtaling PL, Khalil MK, Thomas JD, Jaber WA. Mortality rate in patients with diastolic dysfunction and normal systolic function. Arch Intern Med. 2011;171:1082-1087.

7. Nagueh SF, Appleton CP, Gillebert TC, Marino PN, Oh JK, Smiseth $\mathrm{OA}$, et al. Recommendations for the evaluation of left ventricular diastolic function by echocardiography. J Am SocEchocardiogr. 2009;22(2):107-133.

8. Jong P, Yusuf S, Rousseau MF, Ahn SA, Bangdiwala SI. Effect of enalapril on 12-year survival and life expectancy in patients with left ventricular systolic dysfunction: A follow-up study. Lancet. 2003;361:1843-1848.

9. Mandinov L, Eberli FR, Seiler C, Hess OM. Diastolic heart failure. Cardiovasc Res. 2000;45:813-825.

10. Kass DA, Solaro RJ. Mechanisms and use of calcium-sensitizing agents in the failing heart. Circulation. 2006;113:305-315.

11. Gonzalez DR, Treuer AV, Castellanos J, Dulce RA, Hare JM. Impaired S-nitrosylation of the ryanodine receptor caused by xanthine oxidase activity contributes to calcium leak in heart failure. J Biol Chem. 2010;285:28938-28945.

12. Fischer M1, Baessler A, Hense HW, Hengstenberg C, Muscholl M, Holmer S, Döring A, Broeckel U, Riegger G, Schunkert H. Prevalence of left ventricular diastolic dysfunction in the community. Results from a Doppler echocardiographic-based survey of a population sample. Eur Heart J. 2003 Feb;24(4):320-8.

13. Kloch-Badelek M, Kuznetsova T, Sakiewicz W, et al. Prevalence of left ventricular diastolic dysfunction in European populations based on cross-validated diagnostic thresholds. Cardiovasc Ultrasound. 2012;10:10. Published 2012 Mar 19. doi:10.1186/1476-7120-10-10

Copyright: (C) the author(s), 2019. It is an open-access article distributed under the terms of the Creative Commons Attribution License (CC BY 4.0), which permits authors to retain ownership of the copyright for their content, and allow anyone to download, reuse, reprint, modify, distribute and/or copy the content as long as the original authors and source are cited.

How to cite this article: Arora R, Arora A. Prevalence of Diastolic Dysfunction in Asymptomatic Young and Middle Aged Individuals Attending a Tertiary Care Hospital. Asian J. Med. Res. 2019;8(3):ME01-ME03.

DOI: dx.doi.org/10.21276/ajmr.2019.8.3.ME1

Source of Support: Nil, Conflict of Interest: None declared. 